\title{
Creative Writing In Alcohol, Tobacco, And Other Drug Education
}

Ronald D. Williams, Mississippi State University, USA

Amber R. Williams, New Hope Middle School, USA

\begin{abstract}
Health educators in elementary and secondary schools should seek collaborations with teachers of other subjects to enhance health education curriculum. The strategy described in this article details a potential collaboration between health education and language arts units. The activity enhances both drug education knowledge gains and creative writing skills among junior high/middle school students.
\end{abstract}

Keywords: Creative Writing; Drug Education; Collaboration

\section{INTRODUCTION}

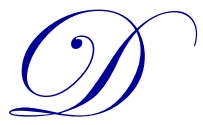

ue to the limited time and resources in schools, health educators have been forced to resourcefully collaborate with instructors of other subjects in an effort to deliver health education to students (Kann, Telljohan \&Wooley, 2006). One unique collaborative partner is language arts, as students are frequently required to participate in creative writing. The writing process itself can foster an environment of positive and healthy behaviors; therefore, combining health concepts with creative techniques can be a rewarding experience for students (Burton \& King, 2004). Education literature suggests that such partnerships with language arts have been successful in other disciplines (Alber, 2001; Donaldson, 2001; Rule, Carnicelli, \& Kane, 2004); therefore, health educators should also seek this alliance.

\section{Grade Level}

This technique is appropriate for students in grades 6-8 in a Language Arts/English or Health class. It is suggested that health education and language arts instructors collaborate to develop assignments. This assignment will assist in meeting the following National Health Education Standards:

1. Health Education Standard \#1 - Students will comprehend concepts related to health promotion and disease prevention to enhance health.

2. $\quad$ Performance Indicator 1.8.1 - Describe the benefits of and barriers to practicing health behaviors

3. Performance Indicator 1.8.7 - Analyze the relationship between healthy behaviors and personal health

\section{ASSIGNMENT OBJECTIVES AND MATERIALS NEEDED}

Upon completion of this activity, students will:

1. identify benefits of being drug-free and risks of drug use

2. develop creative works centered around positive health outcomes of being drug-free

Only pencil and paper are required for students. Instructors may utilize a computer and projector to show examples if needed. 


\section{Activities and Strategies}

\section{Health Education}

The activities in this lesson should be used to supplement assignments that may be a part of traditional drug prevention curricula. Health instructors should appropriately discuss the health concepts of drug use according to evidence-based programs that exist or according to the health education standards set for each school district. Instructors can then introduce the creative writing assignment by having students discuss aloud one particular drug. For example, the instructor can ask students to discuss what they know about tobacco's impact on health. Students can be asked to write down the health impacts of tobacco use. As students list the negative health impacts of tobacco, the instructor should also encourage students to write down the health benefits of remaining tobacco-free. The instructor should facilitate classroom discussion about these positive and negative health impacts and how they may affect each person's life.

After the discussion, the instructor can then introduce the creative writing assignment by giving students a writing prompt relating to tobacco use. An example prompt could be "Write a poem describing the health consequences of tobacco use and why you should be tobacco-free." The instructor should then explain that this assignment is part of a project with the Language Arts or English departments, so students will be writing the poems in those classes.

\section{Language Arts}

Activities in this lesson should supplement other lessons on creative writing. Poetry is one of the simplest forms of creative writing taught at the middle school level; therefore, it lends itself to this activity. However, other methods of creative writing can be utilized. Language Arts instructors should introduce forms of creative writing before beginning this activity. Once students are introduced to the writing methods to be used in this activity, the assignment should be reiterated to the students as it was given by the health education instructor. Language arts instructors should also provide the specific type of poetry that will be used. An example lesson activity and prompt is provided in Table 1.

Table 1: Examples of Drugs, Creative Writing Styles, Themes, and a Finished Work

\begin{tabular}{|l|l|l|}
\hline Types of Drugs & Creative Writing Styles & Examples of Themes \\
\hline Alcohol & Shape poem & Peer pressure \\
Cigarettes & Acrostic poem & Effects on the drug user \\
Smokeless tobacco & Diamante poem & Effects of the user's family \\
Marijuana & Free verse poem & Addiction \\
Inhalants & & \\
\hline Example of an acrostic poem about peer pressure and cigarettes: & \\
Cancer stick & \\
Inhale, exhale, expire & \\
Getting harder to breathe & \\
All I had to do was say no & \\
Real friends would not have pressured me & \\
Exactly the wrong choice & \\
Too bad I didn't say no & \\
To fit in, I puffed away \\
Even though I knew it was bad \\
Smoke free is where I should be
\end{tabular}

\section{Assessment Technique}

Health education instructors should assess the creative writing works on the basis of correct information regarding health impacts of the particular drug use. The assessment will change based on the drug topic and prompt questions. It is important to note the accuracy of students' information regarding the specific drugs. Language Arts instructors should utilize assessment techniques related to the correct forms of creative writing. Table 2 provides a 
sample rubric. Additionally, ReadWriteThink, a partnership between the International Reading Association and the National Council of Teachers of English, provides examples of assessment methods for various forms of creative writing (Classroom Resources, 2010).

Table 2: Sample Rubric for Creative Writing Assignment in Drug Education

\begin{tabular}{|c|c|c|c|c|c|}
\hline & \multicolumn{4}{|c|}{ Criteria } & \multirow[t]{2}{*}{ Points } \\
\hline & $\mathbf{0}$ & 1 & 2 & 3 & \\
\hline Creative Writing & $\begin{array}{l}\text { Incorrect format } \\
\text { and unacceptable } \\
\text { content }\end{array}$ & $\begin{array}{l}\text { Either format or } \\
\text { content is } \\
\text { acceptable, but not } \\
\text { both }\end{array}$ & $\begin{array}{l}\text { Format and } \\
\text { content are } \\
\text { acceptable, but not } \\
\text { entirely correct }\end{array}$ & $\begin{array}{l}\text { Correct format is } \\
\text { used and writing is } \\
\text { interesting }\end{array}$ & \\
\hline $\begin{array}{l}\text { Drug Content \& } \\
\text { Theme }\end{array}$ & $\begin{array}{l}\text { Work shows no or } \\
\text { incorrect } \\
\text { knowledge of drug } \\
\text { issues }\end{array}$ & $\begin{array}{l}\text { Work shows very } \\
\text { little knowledge of } \\
\text { drug issues }\end{array}$ & $\begin{array}{l}\text { Work shows some } \\
\text { knowledge of drug } \\
\text { issues }\end{array}$ & $\begin{array}{l}\text { Work shows } \\
\text { correct knowledge } \\
\text { of drug issues }\end{array}$ & \\
\hline $\begin{array}{l}\text { Grammar \& } \\
\text { Spelling }\end{array}$ & $\begin{array}{l}\text { Work has more } \\
\text { than four grammar } \\
\text { or spelling errors }\end{array}$ & $\begin{array}{l}\text { Work has more } \\
\text { than three or four } \\
\text { grammar or } \\
\text { spelling errors }\end{array}$ & $\begin{array}{l}\text { Work has no more } \\
\text { than two grammar } \\
\text { or spelling errors }\end{array}$ & $\begin{array}{l}\text { Work has no } \\
\text { grammar or } \\
\text { spelling errors }\end{array}$ & \\
\hline & & & & & Total $=$ \\
\hline
\end{tabular}

\section{CONCLUSION}

There are numerous examples of successful partnerships between language arts and primary subjects including earth science, chemistry, and geography (Alber, 2001; Donaldson, 2001; Rule, Carnicelli, \& Kane, 2004). Less is known about the potential collaboration between language arts and health education, yet there exists significant potential in this partnership. Resourcefully, collaboration has been a prerequisite for successful elementary and secondary health educators in light of the increasingly limited resources given to school health education. Since health education is no longer a priority in many schools, the collaborative partnership described here may be able to assist health educators in delivering health content knowledge on drug use through the language arts curriculum. In doing so, students will gain practice in creative writing techniques, while language arts teachers will also benefit from receiving tailored writing prompts for student assignments.

\section{AUTHOR INFORMATION}

Dr. Ronald Williams, Jr. is an Assistant Professor in the Department of Food Science, Nutrition, and Health Promotion at Mississippi State University. He has extensively researched issues in substance abuse including college alcohol use, tobacco prevention and cessation, and smoke-free policy implications, as well as serving as lead evaluator for multiple substance abuse prevention and treatment programs. E-mail: rwilliams@fsnhp.msstate.edu (Corresponding author)

Mrs. Amber Williams is certified and has taught Language Arts at the middle school grade level in multiple states for nine years. She has been active in Professional Learning Communities, as well as curriculum and assessment development. E-mail: amberrwilliams@hotmail.com

\section{REFERENCES}

1. $\quad$ Alber, M. (2001). Creative writing and chemistry. Journal of Chemistry Education, 78(4), 748.

2. Burton, C.M. \& King, L.A. (2004). The health benefits of writing about intensely positive experiences. Journal of Research in Personality, 38(2), 150-163.

3. Classroom Resources. ReadWriteThink. Retrieved May 10, 2010 from http://www.readwritethink.org/classroom-resources/lesson-plans/.

4. Donaldson, D. P. (2001). Teaching geography's four traditions with poetry. Journal of Geography, 100(1), 24-31. 
5. Kann, L., Telljohann, S.K., \& Wooley, S.F. (2006). Health education: Results from the school health policies and programs study 2006. Journal of School Health, 77(8), 408-434.

6. Rule, A.C., Carnicelli, L.A., \& Kane, S.S. (2004) Using poetry to teach about minerals in earth science class. J Geoscience Education, 52(1), 10-14. 